\title{
Hour Times Micromole per Liter per Meter Squared
}

National Cancer Institute

\section{Source}

National Cancer Institute. Hour Times Micromole per Liter per Meter Squared. NCI

Thesaurus. Code C111217.

Hours times micromoles per liter, divided by meters squared. 